個人の経路変更可能性に着目した動的地区交通シミュレーションモデルの開発*

\title{
The Development of Traffic Simulation Model for Personal Route Change Possibility*
}

\author{
菊池 守久**、坂本 邦宏***、久保田 尚**** \\ By Morihisa KIKUCHI**, Kunihiro SAKAMOTO*** and Hisashi KUBOTA****
}

\section{1. はじめに}

計算機能力の発展に伴い、市街地レベルにおける交通 渋滞等の交通インパクトの評価手法としてシミュレーシ ヨン技法が盛んに利用されてきている。しかし、これま でに確立された交通シミュレーションに用いられている 交通量算出手法は広域的な道路ネットワークを対象とし、 また最短時間経路探索による配分を行っているものが多 い。一方で、自動車運転者（以下運転者）の挙動、人間 工学的データや走行経路などの選好意識に関するデータ も十分に蓄積されていないのが現状である。

そこで本研究では、第 1 に実走行実験によって運転者 (U)経路選択行動 ${ }^{1)}$ を解析、モデル化する。第 2 に埼玉大 学で開発を続けている地区交通シミュレーション、tissNET (traffic impact simulation subsystems for road NETwork） ${ }^{2)}$ に途中経路変更 ${ }^{3)}$ の概念として組み込み、 時々刻々変化する交通状況による動的な経路変更など運 転者個人の経路選択行動を表現することによって、現実 的でミクロな交通状況の再現を可能にすることが目的で ある。

\section{2. 交通シミュレーションにおける経路選択メカニズム の分類}

交通シミュレーションでは、その開発目的によって経 路選択メカニズムをどのように扱うかが決まってくる。 交通シミュレーションにおける代表的な経路選択モデル をその手法別に分類し以下に示す。

（1）ネットワーク製作者の主観と経験による案分

シミュレーションを行なう際、ネットワーク製作者が 対象地域の人口比などを用いて自身の主観的な観点から

* キーワード : 経路選択、ネットワーク交通流

** 学生会員 埼玉大学大学院

浦和市下大久保 255

TEL 048-855-7833 FAX 048-855-7833

*** 正会員 工学修士 埼玉大学工学部建設工学科助手 浦和市下大久保 255

TEL 048-858-3549 FAX 048-855-7833

**** 正会員 工学博士 埼玉大学工学部建設工学科助教授 浦和市下大久保 255

TEL 048-858-3554 FAX 048-855-7833
経路に案分する手法である。この方法は理論的根拠が少 ないが実務的に多く用いられている。

（2）交差点での右左折直進率を用いた経路選択

個々の車両の経路そのものにあまり重点をおかない手 法として、各交差点において右左折直進の割合を設定し 車両の経路選択を表現しているものがある。代表的なも のを以下に挙げる。まず、齋藤ら ${ }^{4)}$ はネットワークの交 通状況、道路属性、交差点の交通容量によるリンク間 OD 交通量をもとに、各リンクの交通量や交差点での右左折 直進率などを推定している。また、堀田ら ${ }^{5)}$ によると片 側 2 車線以上の道路における右側車線からの左折や左側 車線からの右折といった非現実的な右左折を除く運用可 能な右左折方法をパターン化した条件付き右左折行動を 導入することで、ネットワーク製作者がリンクにおける 右左折の確率を任意に定義することを可能としている。 さらに、中川ら ${ }^{6}$ は (3) で述べる Dial のアルゴリズム を参考にして経路を選択する（目的地が決定された）車 両と、右左折率に応じて進行方向を決定する（目的地が 決定されていない）車両を同時に発生させることを可能 としている。

\section{（3）確率的経路配分モデル}

確率を用いて各車両の経路を決定するといった確率的 経路配分モデルには以下のようなものが挙げられる。ま ず、岡村ら ${ }^{7)}$ は運転者ををあらかじめ経路選択層と経路 固定層の 2 種類に分割している，経路固定層は自由走行 による走行時間をもとに経路選択確率で配分され、経路 選択層は一定時間間隔で算出された旅行時間をもとに経 路選択確率が更新される。両層とも Dial 配分によって 各経路の経路選択率が決定される。また、森津ら ${ }^{8)}$ は経 路選択行動モデルとして目的地までの所要時間に基づき 最短時間経路を走行する経路選択モデルと、リンク走行 終了時に経路決定時の想定時間と実走行時間との差を経 路変更の要因とする経路変更モデルの 2 つに分けている。 ただし、経路選択モデルでは予定経路と代替経路の時間 差が小さい時には経路変更の可能性が低いとしている。 さらに、飯田ら ${ }^{9)}$ は運転者の経路選択をシミュレートす る経路選択シミュレーションと道路上の交通流を再現す るフローシミュレーションとで構成している。運転者は 経路固定層、経験利用層、情報利用層に分けられ、確率 
分布による誤差を与えられた見込みリンク走行費用を用 いて、経路途上の全ノードにおいて現在位置から目的地 までの見込み費用を最小とする経路を選択する。

\section{（4）最短経路探索モデル}

ダイクストラ法などを用いて目的地までの時間（コス ト）を最小とする経路を決定するモデルには以下のよう なものが挙げられる。まず、井上ら ${ }^{10)}$ によると各車両 がリンクの終端部分に達すると、一定時間間隔で探索さ れた目的地までの最短時間経路を選択する。ただし、特 定けリンクに車両が集中することを避けるためあらかじ め探索された経路を数本記憶しておき、その中からラン ダムに選択される。また、堀口ら ${ }^{11)}$ は一定時間間隔で 旅行時間などを用いて最短時間経路探索を行い、各リン クの目的地別方向表示を更新する。それによって各車両 が次に流入するリンクを選択する。その後、Dial 配分を 用いている。

\section{3. 経路選択メカニズムの課題とその対応策の整理}

\section{（1）課題の整理}

本章では既存の経路選択メカニズムおける課題とその 対応策の整理、さらに地区交通シミュレーションシステ ム tiss-NET に導入する経路選択メカニズムについて述 バる。

\section{課題 $\mathrm{A}$}

目的地までの旅行時間（コスト）を唯一の経路選択・ 経路変更要因として用いているものが多い。確率モデル を組み込むことによって、ばらつきを与えているものも あるが、機械的な操作による経路選択となっている。

\section{課題 B}

シミュレーションを行なう際、対象となる道路ネット ワークはシミュレーション製作者があらかじめ意図的に 作成した道路ネットワーク、もしくは存在する全ての道 路ネットワークにおいて製作者によって任意に選ばれた 経路が利用され、車両を走行させることがある。

課題 $\mathrm{C}$

実際の交通行動をシミュレーションで再現するために は、運転者の個人属性や選好意識、ネットワーク認知度 などをモデル化し組み込むことが必要であるが、現在は 未だメカニズムが解明されていない。

\section{（2）対応策の方向性}

これらの課題に対し、取り組んでいくべき対応策を示 し、最後にその実現案を提示する。

\section{対応策 $A$}

運転者の経路選択行動は、運転者の免許保有期間・運 転頻度・その地域への来訪回数などの個人属性、また沲 滞や先詰まりなど走行時の交通状況、さらには道路幅員 や右左折による影響など様々な要因が複雑に関係しあっ
て生じているものと考えられる。

このため、まず運転者の置かれている状況、たとえば、 運転経験・運転頻度による歩行者の有無や道路幅員など による道路選択の選好意識の違い、また、運転者はどれ くらいの混雑で渋滞と認識するのか、さらにどれくらい で回避しようと考えるのか、言い換えれば、運転者が道 路を走行する時にどのような環境が最適な道路環境であ るのか、などによる経路選択行動の違いを解明していく ことが必要である。

\section{対応策 B}

より簡易的にシミュレーションを実行する上では効率 的な手法であると考えられるが、実際の交通現象を再現 するという観点からみると恣意的判断が紛れこむ恐れが ある。よって運転者が存在を知らない、また知っていた としても利用しない道路を選択することとなったり、逆 に実際の走行では使用されている道路がネットワークに 存在されていないといったケースが生じる可能性もある。 経路指定の労力も無視することができない。

このため、運転者の地域への来訪経験の違いなどによ つて道路ネットワークの認知度にどのような影響を及ぼ しているのか、さらにどのような要因によって運転者は ネットワークを認知していくのかを解明していく必要が ある。最終的には、対象地域の全ての道路でネットワー クを形成し、その道路ネットワークを個々の車両が選択、 変更していくことが望ましい。

対応策 $\mathrm{C}$

シミュレーションにおいても各車両自身が走行経路を 決定し走行することが望ましい。しかし、実際に経路を 決定する過程として、あらかじめ目的地まで経路を決定 する運転者もいれば、途中まで経路を決定しそれ以降は 走行途中に経路を決定していく運転者もいるだろう。こ のように複雑なモデルをシミュレーションに組み込むここ とは現段階では不可能に近い。

運転者の交通行動は以上のような要因が幾重にも複雑 に絡み合って成立している。そのため詳細な行動モデル を構筑するためには、明らかにしなければならないこと が数多く存在すると考えられる。そこで、運転者の経路 選択行動を簡略した、いわば擬似的な行動モデルを経路 選択メカニズムとして組み込むことが考えられる。

\section{（3）本研究の対象範囲}

本研究では地区交通シミュレーターに経路選択メカニ ズムを組み込むことを目的としている。地区交通シミュ レーションでは車両 1 台 1 台を再現することが重要とな るため、運転者の経路選択行動に着目した経路選択モデ ルを構筑し、地区交通シミュレーションに組み込んでい くことが必要と考えられる。具体的には、選択する経路 を「あらかじめ対象ネットワーク上に存在する道路で OD 間を結んでおいた連続した 1 本（数本）の線」といった 考え方をするのではなく、実用化を目指す簡略モデルと 
して各車両がノードに到着した時点にそのノードに接続 しているリンクに対して利用・非利用を判断する経路選 択メカニズムを提案する。4 章でその概念について説明 する。

\section{4. 動的経路変更の概念}

（1）基本概念

前述した通り、従来のシミュレーションモデルでは実 際り交通行動との間にいくつかの矛盾点が挙げられる。

そこで、本研究ではシミュレーターへの導入を前提と して運転者が目的地に到着するまでに行なう経路選択行 動を以下のように考える。

まず、運転者は出発時点である程度の経路（順路）を 決定して走行を開始する。この経路は何らかの基準（経 験や情報）によって決定されると考えるのが自然である が、本研究で扱うシミュレーターにおいてはダイクスト ラ法を用いて目的地までの最短時間経路を決定する。そ して、運転者は道路を走行中その先に交差点があること を過去の経験や実際に目で見ることで認知する。交差点 を認知できなかった場合には道なりの道路を走行するも のと考えられる。交差点を認知した場合、その交差点に おいてその時の交通状況によって、あらかじめ利用しよ うとしていた道路を実際に利用するかどうかを判断する。 こけときあらかじめ決めていた経路を利用する場合には 予定通りに交差点を通過するが、何らかの要因によって 実際に走行する経路を変更する場合、その経路以外の経 路に対していくつかの要因によって実際に走行するリン クを選択して走行する。これらの操作を繰り返すことに よって最終的に目的地に到着する。

このように、運転者は固定された経路のみを使用する のではなく、事前にいくつかの使用する道路（経路）の 候補を決めて出発し、交通状況などに応じて「こういう 場合にはこの経路を使う」といった、IF-THEN ルール ともいうべき手続き経ていることが、筆者らの別の研究 からも明らかにされている ${ }^{12)}$

以上より、(1)ダイクストラ法によって決定される初期 経路（最短時間経路）を修正すること、および(2)運転者 が認知した交差点における経路変更の可能性を表現する こと、の 2 つを表現できるモデルを検討した。そこで運 転者の時系列的な経路選択行動を表現し、さらに「リン ク心選択性」という概念を用いて旅行中に運転者が交通 状況や道路状況等の要因によりノード（交差点）におい て接続リンク（道路）の利用可能性を判断し、個々の車 両の走行経路を決定するという「初期経路利用判別モデ ル、「選択可能リンク判別モデル」の 2 つの疑似行動モ デルを内包した「2 段式経路変更モデル」を提案する (図 -1 )。

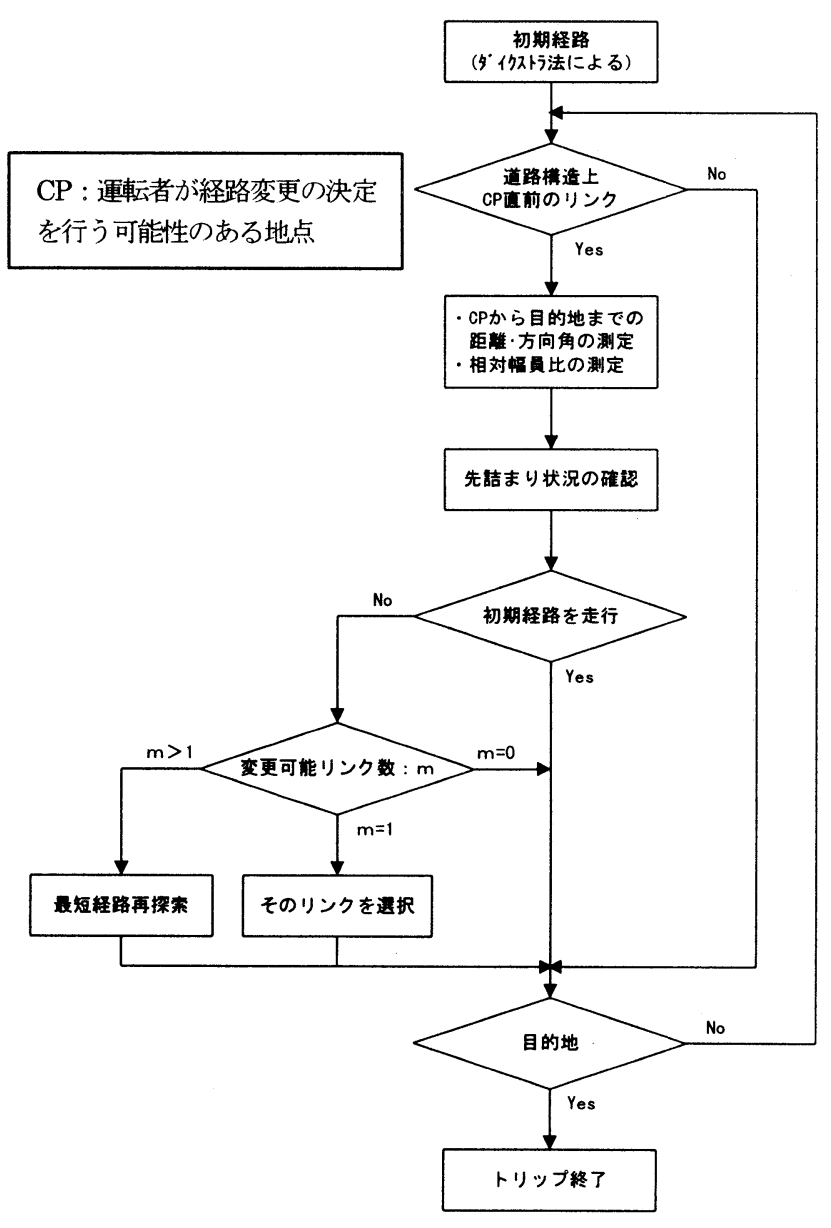

図-1２段階式経路変更モデルのフロー

道路構造
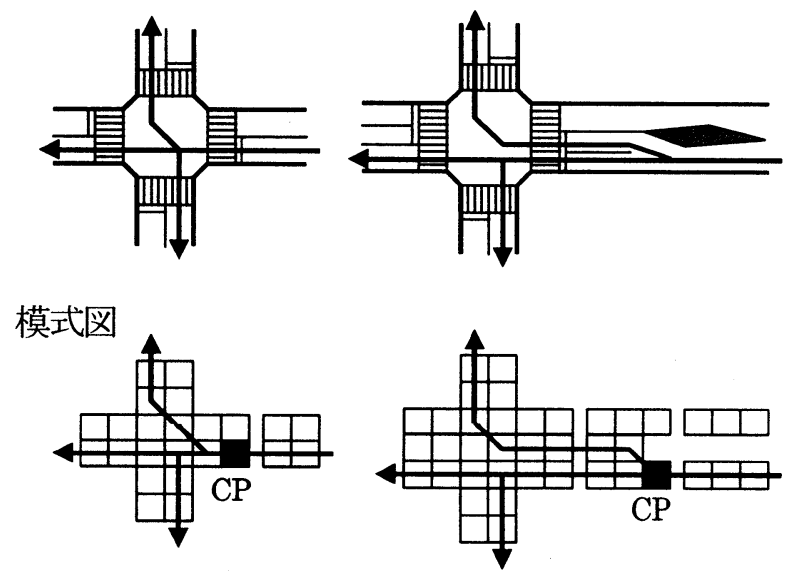

図-2 CP (Changeable Point)

（2）２段式経路変更モデルの特長

本モデルは、(1)運転者が予定していたリンク（初期経 路）について、交通状況や道路状況によって利用·非利 用を判断し、(2)非利用と判断された時に初めてそれ以外 のリンクについて利用·非利用を判断するモデルである。 このモデルでは運転者の経路決定行動を時系列的に 2 段 階に分けて表現している。このように経路変更モデルを 2 段階に分けることによって、シミュレーションではま ず初期経路である 1 本のみのリンクに対して利用・非利 
用の判断を行なえばよく、初期経路を利用するとなった 場合にはそれ以降の計算を省略できるといった利点を備 えている。また、本モデルは運転者が予定していた経路 を交通状況などにより害際に利用するのか、それとも別 の経路に変更するのか、といった時系列的な行動をモデ ル化することが可能となり、実際の交通行動に近い現実 的なモデルであると考えられる。

さらに、本モデルでは道路構造など物理的な経路変更 要因は、ノード・リンク単位に分割した情報を使用する ため、地理情報システム（GIS）を利用することによっ て、データ取得が容易となり入力時のミスが削減される といった利点が挙げられる。

（3）初期経路利用判別モデル

まず、各車両は暫定的な初期経路に基づいてトリップ を開始する。各車両が経路変更可能なノード（シミュレ ーション上では具体的に車両位置が決定される場所であ る Changeable Point ${ }^{13)}$ 以下 CP) (図-2) に到着すると 第 1 のモデルである「初期経路利用判別モデル」により、 そのノードにおいて初期経路とされているリンクについ て交通状況と道路構造を経路決定要因として用い、その リンクが運転者にとって利用可能（認知可能）なリンク かどうかの判断を行なう。この結果、初期経路が利用可 能であれば経路を変更することはない。

\section{（4）選択可能リンク判別モデル}

初期経路が利用不可能とされた場合、第 2 のモデルで ある「選択可能リンク判別モデル」を用いて対象ノード に接続している残りのリンクそれぞれに対し利用可能か どうかの判断を行なう。その結果、利用可能リンクが 1 本であればその経路を利用することになるが、2 本以上 であればそれらのリンクに対して初期経路決定手法と同 様、ダイクストラ法を用いて最短経路を探索し利用リン クを決定する。ここで、例外として利用可能経路が存在 しない（利用可能リンク数が 0 本）と判断された場合に は、便宜上初期経路を走行するもとする。このモデルは ロジットモデルを用いて構筑していることから、対象と しているリンクそれぞれに対して利用確率が求まる。そ のためこれらの利用確率を比較し利用確率が最も大きな リンクを走行させることも可能である。しかし、交通シ ミュレーションに組み込むことを目的としているため計 算量の削減を考慮し、あらかじめ設定されている初期経 路を走行させることとする。

以上の操作を各ノード (CP) で繰り返し、車両が目 的地に到着した時点で終了する。

\section{（5）動的経路変更要因}

動的経路変更モデルを構築するにあたり、非集計分析 におけるモデルの推定を行なう。ここではその説明変数
について説明する。
(a) 個人特性

運転者の目的地周辺への来訪回数、運転免許保有期間、 自動車運転期間、運転頻度を用いた。

(b) 相対幅員比 (図-3)

現在走行しているリンクの道路幅員（歩道部を含む）

$\left(W_{\mathrm{a}}\right)$ に対する走行予定リンクの道路幅員 $\left(W_{\mathrm{b}}\right)$ を相 対幅員比 $\left(W_{\mathrm{b}} / W_{\mathrm{a}}\right)$ とした。

(c) 方向角と目的地までの距離（図-4）

方向角は対象交差点を基準として車両の走行予定方向 と目的地までの振れ角で表す。また距離とは対象交差点 から目的地までの直線距離を用いる。

（d）交差点属性

交差点での信号の有無、道路案内板の有無を交差点属 性とした。

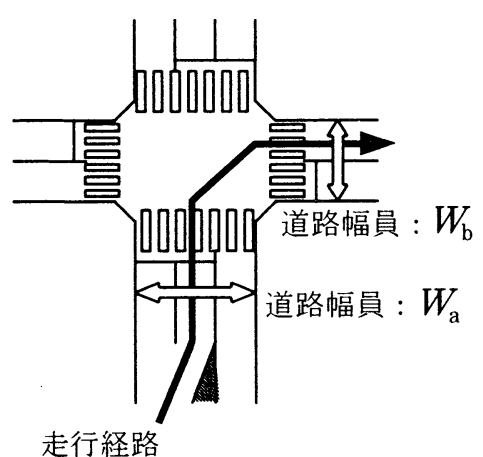

図-3 相対幅員比

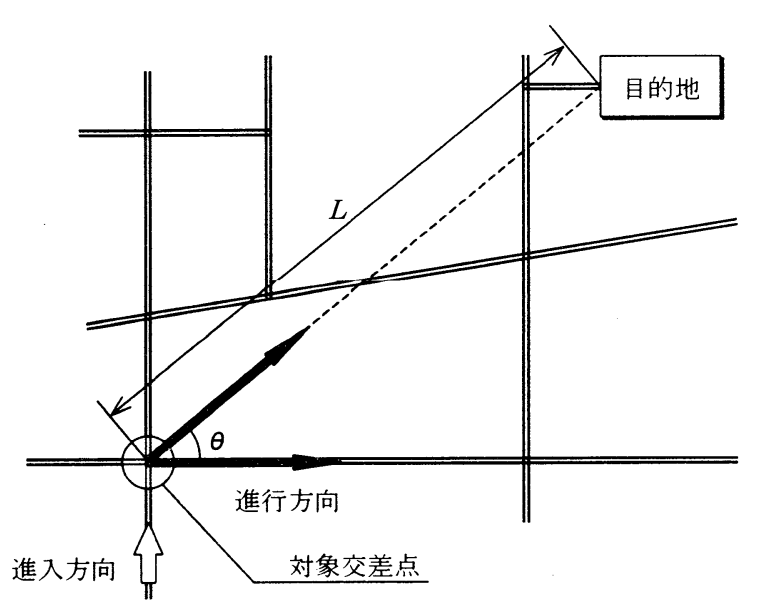

図-4 方向角と目的地までの距離

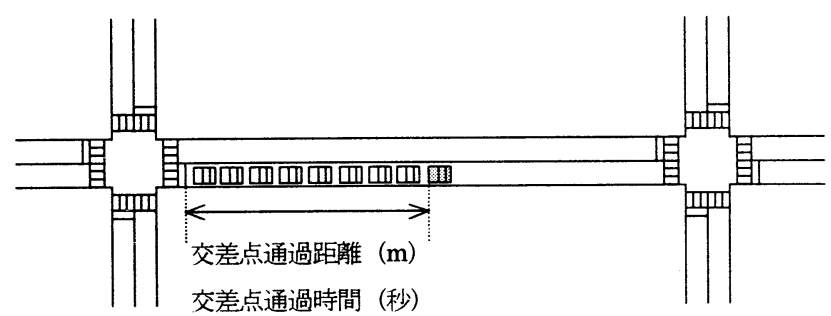

図-5＼cjkstart交差点通過時間と交差点通過距離 
（e）交差点通過時間と交差点通過距離（図-5）

車両がリンクを走行中、リンク端部の交差点の信号や、 先詰まりによる待ち行列の最後尾につくことで停止する ことがある。このような場合、車両が停止した地点から 交差点までの距離を交差点通過距離、その時に要した時 間を交差点通過時間とする。

\section{（f）交差点通過方法}

交差点を通過する際、直進（道なり）、左折、右折に よる通過時間の差などを考慮する。

（g）先詰まり状況

運転者自身が判断できる範囲において、対象交差点を 通過した後のリンクの交通状況が、先詰まりを生じてい ないかどうかを判別する。

\section{5. 動的経路変更モデルの構築}

\section{（1）走行実験の概要}

動的経路変更モデルを構築するにあたり 1997 年 10 月〜 12 月に走行実験を行なった ${ }^{12)}$ 。実験地区は、運転 者の経路選択機構を調查することを目的としたため、被 験者の運転経験の少ない地域と考えられる JR 戸田駅を 起点、JR 南浦和駅を終点とする地域 (直線距離 : $3.2 \mathrm{~km}$ ) とした（図-6）。被験者は埼玉大学の学生 4 人で、走行 前に個人属性のアンケート、対象地区についての認知地 図を作成してもらい、走行後に再度認知地図を作成して もらった。ここで認知地図とは、A4 版の白紙の紙に被 験者が走行すると考えられる範囲内で認知している全て

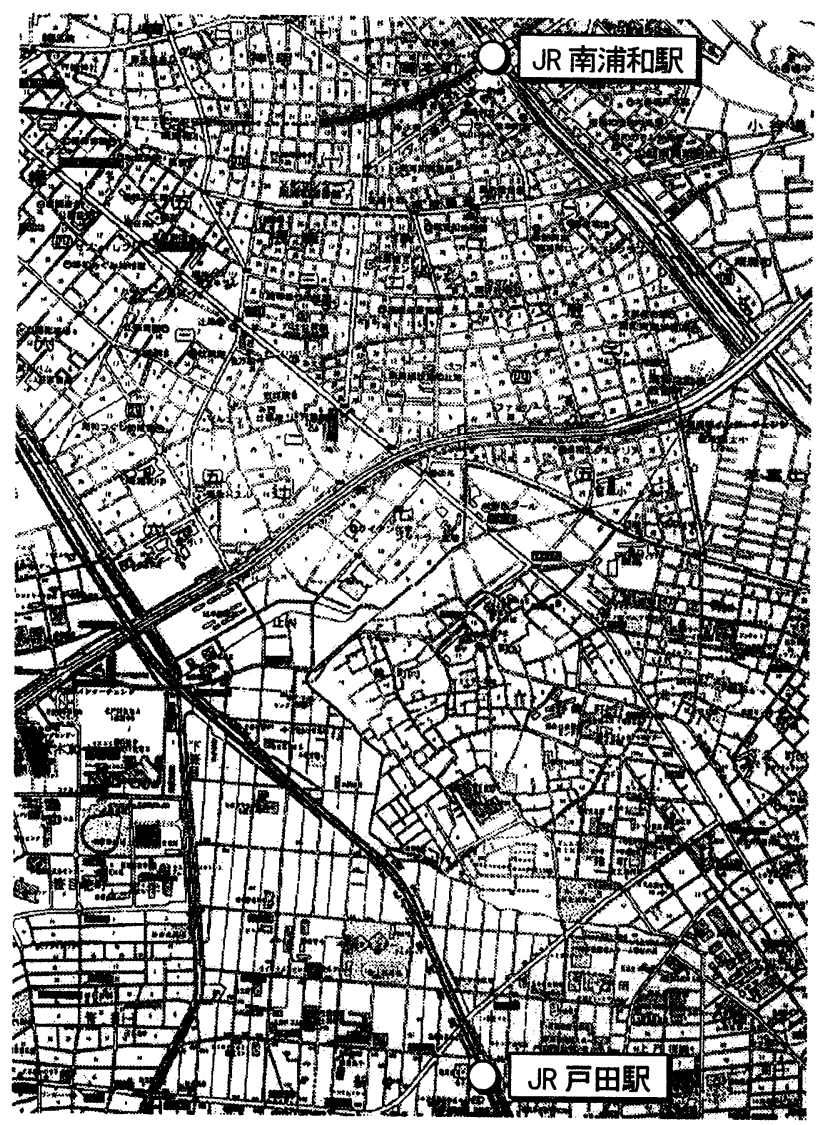

図-6 走行実験地域地図
の道路、さらに対象地区内の建物や交差点名称、ランド マークなど覚えているもの全てを記入してもらったもの とする。走行に際し「被験者にとって最適な経路を走行 する」という条件の下で走行してもらった。被験者 4 人 に対し 36 トリップのデータを取得した。

モデルの構築にあたり、非集計分析の考え方を適用し 2 項ロジットモデルによるパラメータの推定を行なった。 以下にその推定結果を示す。

\section{（2）初期経路利用判別モデル}

運転者が交差点で「初期（予定）経路を利用する、初 期（予定）経路を利用しない、のどちらか一方を必ず選 択する」という 2 項ロジットモデルの構築を行なった。 モデルに影響を与える要因として「先詰まり状況」「方 向角」が挙げられた。パラメータ推定結果を表-1に示す。

表-1 初期経路利用判別モデルのパラメータ推定結果

\begin{tabular}{l|c|c}
\hline & パラメータ & $t$ 值 \\
\hline \hline 先詰まり状況 & -3.152 & -4.69 \\
方向角 & -0.017 & -1.73 \\
定数項 & 4.511 & 7.34 \\
\hline$\rho^{2}$ (尤度比) & \multicolumn{2}{|c}{0.170} \\
\hline 的中率 & \multicolumn{2}{|c}{96.6} \\
\hline
\end{tabular}

この表から $t$ 值、的中率ともに満足のいく結果が得ら れたが、尤度比が低い推定結果となった。これは本研究 では考慮に入れていない交差点の有無の認知や、道路ネ ットワークの認知状況等による経路変更可能性への影響 など、その他の要因によって初期経路利用の判断を行な っている可能性もあるのではないかと考えられる。

\section{（3）選択可能リンク判別モデル}

初期経路利用判別モデルによって初期経路を利用しな いと判断された場合、対象ノードに接続している各リン クに対して「利用する、利用しない、のどちらか一方を 必ず選択する」という 2 項ロジットモデルの構筑を行な った。モデルに影響を与える要因として「方向角」「相 対幅員比」が挙げられた。パラメータ推定結果を表- 2 に 示す。

表-2 選択可能リンク判別モデルのパラメータ推定結果

\begin{tabular}{l|c|c}
\hline & パラメータ & $t$ 値 \\
\hline \hline 方向角 & -0.004 & -0.44 \\
相対幅員比 & 0.042 & 3.35 \\
定数項 & -2.265 & -1.27 \\
\hline$\rho^{2}$ (尤度比) & \multicolumn{2}{|c}{0.377} \\
\hline 的中率 & \multicolumn{2}{|c}{82.1} \\
\hline
\end{tabular}

この表から的中率、尤度比ともに満足のいく結果であ ると考えられるが、方向角の $t$ 值が低くなってしまった。 この原因としては走行実験における初期経路の変更とい 
うサンプルが少なかったため、詳細なデータが取得でき なかったことが原因の 1 つであると考えられる。

初期経路利用判別モデル、選択可能リンク判別モデル ともパラメータ推定を行なう際、4 章（5）(a）で述べ た個人属性を考慮に入れたが満足のいく結果を得ること ができなかった。これは、被験者が学生ということで運 転経験、免許取得期間などに偏りが出たためと考えられ る。このため 6 章で述べるシミュレーションモデルへの 組み込みにあたり、シミュレーションの実行時にかかる 計算量を削減する等の理由から個人属性を削除し、モデ ルの簡略化を行なった。

\section{6. シミユレーションモデルの開発}

\section{(1) tiss-NET の現況}

tiss-NET は地区交通計画を対象としたミクロな交通 状況を再現することを目的としている。このシステムで は道路を「コンパートメント」と定義した長さ $5 \mathrm{~m}$ の単 位に分割し、個々のデータを持った車両が各コンパート メント間でデータを移動させることで車両の移動を表現 しているイベントスキャン型のミクロシミュレーション モデルである。また、本シミュレーターは分割配分を基 礎としており、全体のシミュレーション時間をm分割し、 最初の $1 / \mathrm{m}$ 時間（第 1 フェーズ）はダイクストラ法に よる最短時間経路に車両を発生・走行させる。そして、 $1 / \mathrm{m}$ 時間が経過した時点で実走行により計測されたセク ションタイムを利用し、再度新しい最短時間経路を計算 する。その経路を次の $1 / \mathrm{m}$ 時間に発生する車両の走行経 路とする。この操作を分割回数分だけ繰り返し全交通量 の経路配分を行なっている。そのため、現在 tiss-NET においても経路選択要因として時間のみを用いた配分を 行っている(図-7)。

（2）tiss-NETへの組み込み

tiss-NET では先述した通り、シミュレーション時間 を任意に分割し、セクションタイムを用いて最短時間経 路を再探索している。そこに 5 章で構筑した「動的経路 変更モデル」を組み込む。図-7に示した任意のフェーズ の途中であるとしても、各車両が交差点 (CP) に到着 した時点で経路変更の可能性があると判断された場合に は、途中経路変更が可能となる。結果として、同一 OD の車両でも異なった経路を走行する可能性が発生する。

(3) シミュレーション結果

図-8に示した仮想ネットワークを対象に、シミュレー ションの実行を行った（1200 秒)。シミュレーションの パターンは、(1)現行の分割配分のみ、動的経路変更モデ ルを組み込み(2)全ての道路幅員が同一、(3)リンク 1-9、 リンク 2-8 の道路幅員がその他のリンクの $1 / 2$ 倍、(4)リ ンク $1-9$ の道路幅員がその他のリンクの 2 倍、の 4 通り
である。動的経路変更モデルの再現性を確認するため、 図-9に示したある $1 つ$ ODに着目した。また暫定的な 初期経路は図中の矢印のようになった。各シミュレーシ ヨンにおける車両の経路とその走行台数の結果を図-10 〜13に示す。

パターン(1)では、1200 秒のシミュレーション時間を 6 分割し、200 秒ごとに最短時間経路の再探索を行なつ た。その結果として 6 分割目の経路は初期経路と同じ経 路になった。また、車両がほぼ等時間間隔で発生したた め、どの経路とも走行車両台数に変化が現れなかった(初 期経路は 2 倍）(図-10)。

パターン(2)は、すべての道路幅員を同一にした。リン ク 20-19 を選択する車両が多くみられた。これは、リン

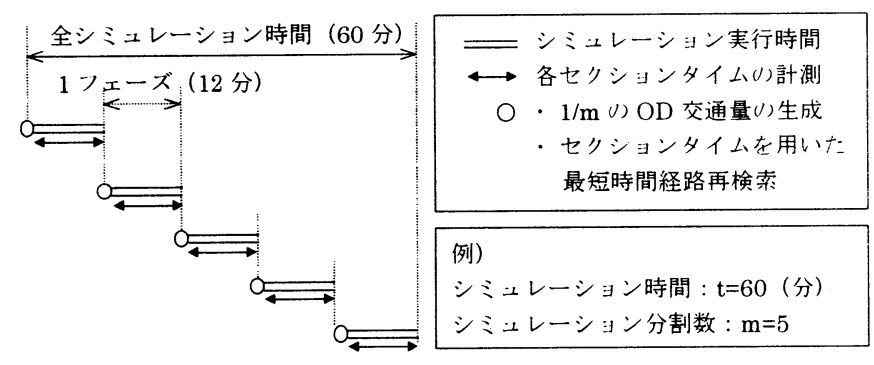

図-7 シミュレーションの進行例

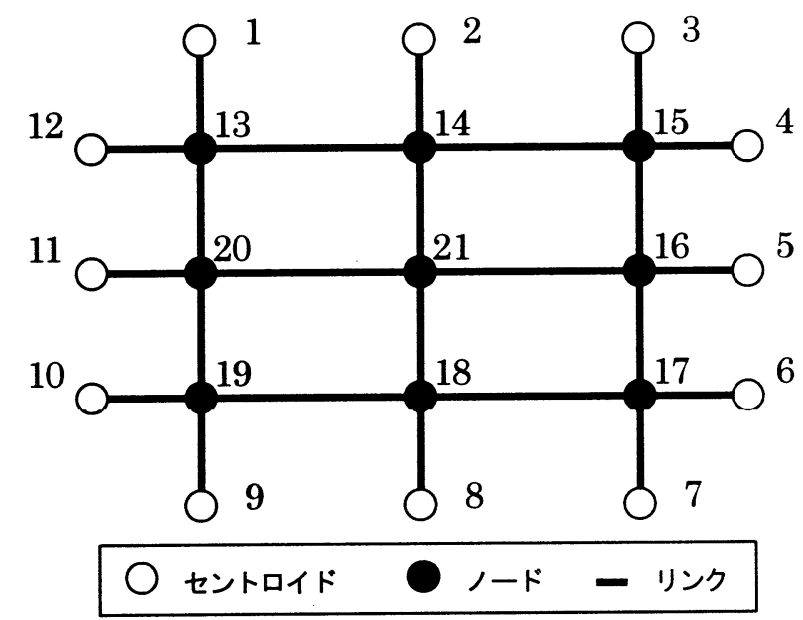

図-8 仮想ネットワーク

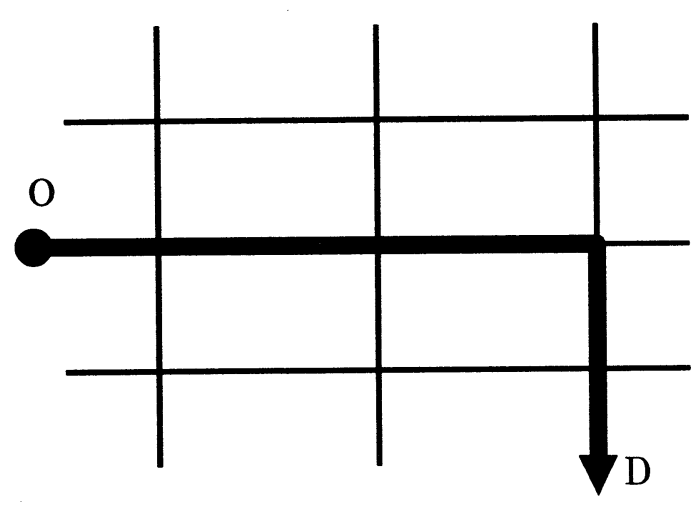

図-9 着目 OD と暫定的な初期経路 
ク 20-21に車両が集中したために初期経路を利用せず、 結果として経路を変更したものと考えられる。また、リ ンク 20-21 と反対方向のリンク 20-13 を利用した車両も みられた（図-11）。

パターン(3)では、リンク 1-9 の幅員を他のリンクの幅 員の 2 倍とし、幹線道路とみなした。そのため方向角が 大きいにもかかわらずリンク 20-13 を利用した車両が大 きく増加した。しかしリンク 20-19 の利用車両がなかっ た。これは、選択可能リンク判別モデルにおいてリンク

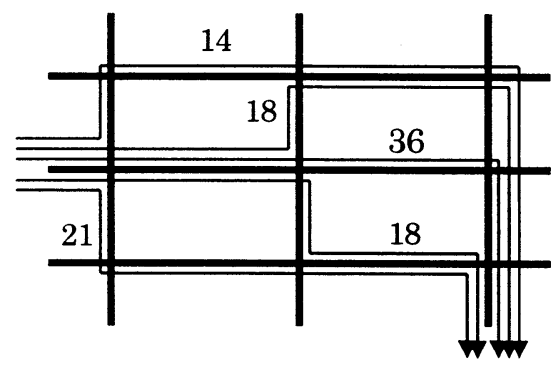

図-10 パターン(1)の車両走行経路（数字は走行台数）

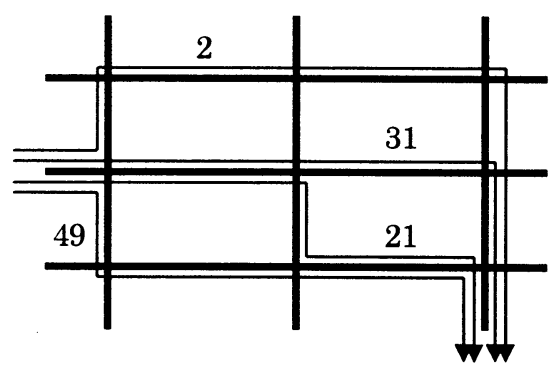

図-11 パターン(2)の車両走行経路（数字は走行台数）

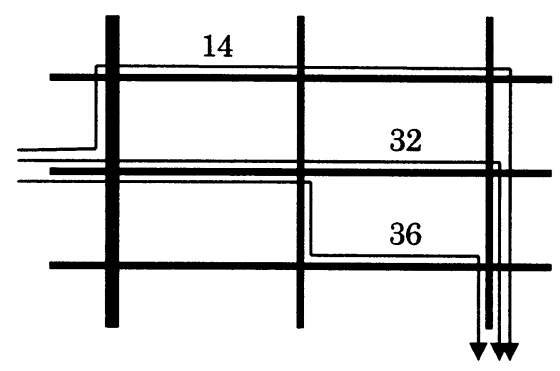

図-12 パターン(3)の車両走行経路（数字は走行台数）

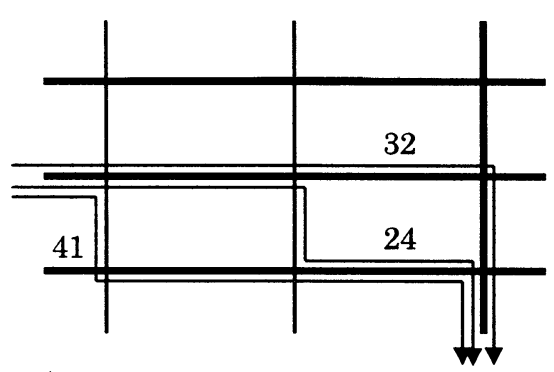

図-13 パターン(4)の車両走行経路（数字は走行台数）
の利用・非利用を判断する際に、ロジットモデルから出 カされたリンク利用確率に乱数を与えることによって最 終的な結果にばらつきを与えていることもこのような結 果の原因の 1 つであると考えられる。(図-12)。

パターン(4)では、リンク 1-9、リンク 2-8 の幅員をそ の他のリンクの幅員の $1 / 2$ とし、地区道路とみなした。 車両走行経路はパターン(2)と近い傾向がみられた。しか し、リンク 20-13、リンク 21-14 は幅員が狭いこともあ り、利用する車両が現れなかった（図-13）。

\section{7. まとめ}

本研究では、まず既存の交通シミュレーションの経路 選択モデルについて分類し、現在抱えている課題を列挙 し、それについての対策を提示した。しかし、運転者の 経路選択行動のメカニズムを解明することは困難である。 そのため対策の実現案として、選択する経路を「あらか じめ対象ネットワーク上に存在する道路で OD 間を結ん でおいた連続した 1 本（数本）の線」といった従来の考 え方ではなく、道路ネットワークをリンクとノードに分 解し、各ノードにおいてリンクの利用・非利用を判断す る疑似行動モデルを提案した。

この疑似行動モデルを構筑するため、実走行実験を行 ない運転者の経路選択に関わる要因を抽出した。さらに 2 項ロジットモデルによるパラメータの推定を行った。

これにより交通シミュレーションに経路選択を組み込む ことが可能となった。このモデルを組み込んだシミュレ ーション結果から、時間だけではなく道路属性などの要 因によって車両がリンクを選択し、結果として経路を変 更していることが確認された。

今後の課題として以下の 4 点が考えられる。まず、本 研究では明らかにすることができなかった運転者の経路 選択行動ににおける運転経験や運転頻度など個人属性を 考慮した行動モデルを構築していくことが挙げられる。 さらに物理的要因についても、今回取り上げた要因以外 にも影響を及ぼしているものをモデルに組み込むことが 可能かどうかを判断していく必要がある。結果としてよ り精度の高いモデルを構築していくことが望まれる。2 点目は、本研究では運転者の時系列的な経路選択行動を 表現した「2 段式経路変更モデル」を提案したが、全て の運転者の経路選択行動がこのモデルで表現できるとは 考えにくい。さらにロジットモデルによるパラメータ推 定結果も全てが満足のいく結果が得られたとは言えない。 よって本研究で構築したモデル以外の経路変更モデルに ついても今後取り組んでいくことが必要であると考えら れる。3 点目として、カーナビゲーションの急速な普及 に伴い情報提供による経路選択行動を把握していくこと が重要となってくる。最後に、運転者はリンク・ノード 単位で経路選択を判断するだけではないことも経験的に 分かっている。それらがどのように組み合わされて経路 
(ネットワーク) が構築されているのかを解明していく ことも今後の大きな課題である。

なお、本研究は平成 10 年度の建設省土木研究所受託研究「ITS 関する基礎的先端的研究」の成果によるものである。

\section{<参考文献 $>$}

1）小山周一、久保田尚、岩崎伸昭、高橋伸夫、杉浦孝臣 ; 情報をコントロールされた自動車運転者の Way Finding 機構に関寸る実験的研究, 土木計画学研究・ 論文集 No.13, pp.603-612，1996.8

2) 坂本邦宏、高橋伸夫、久保田尚 ; セクションを利用し た地区交通のための交通インパクト評価システムの開 発，土木計画学研究・講演集 No.20 (1), pp.493-496, 1997.11

3）岩崎伸昭、久保田尚、坂本邦宏、高橋伸夫 ; 交差点で の個人の経路変更可能性に着目した経路選択モデル, 土木計画学研究・講演集 No.18 (2), pp.509-512, 1995.12

4) 齋藤威; 交通流評価用シミュレータの開発 - 信号制御 アルゴリズムの高度化を目指して - ，月間交通 1997 年 7 月号, pp.82-100

5）堀田都、横田孝義、永井徹 ; 信号現時方法及び車線運 用計画立案システムの開発, 第 17 回交通工学研究発表 会論文報告集, pp.41-44，1997.11
6）中川了爾、大鹿裕幸、久野雅弘、平山正弘; 多目的型 交通シミュレーションシステムの開発，第 15 回交通工 学研究発表会論文報告集, pp.33-36, 1995.11

7）岡村寛明、桑原雅夫、吉井稔雄、西川功；一般街路網 シミュレーションモデルの開発と検証, 第 16 回交通工 学研究発表会論文報告集, pp.93-96, 1996.11

8）森津秀夫、中島正樹 ; 動的経路誘導のための経路選択 行動モデルに関する一考察, 土木計画学研究・講演集, No.19 (2), pp.753-757, 1996.11

9）飯田恭敬、藤井聡、内田敬 ; 道路網における経路選択 を考慮した動的交通流シミュレーション，土木学会論 文集 No.536/IV-31, pp.37-47，1996.4

10）井上博司；道路網交通流の動的シミュレーション手法 に関する研究，土木学会第 48 回年次学術講演会講演概 要集 第 4 部, pp.684-685, 1993.9

11）堀口良太、片倉正彦、赤羽弘和、桑原雅夫 ; ハイブリ ッドブロック密度法を用いた都市街路網の交通流シミ ユレータの開発: AVENUE, 土木学会第 49 回年次学 術講演会講演概要集 第 4 部, pp.760-761， 1994.9

12）久保田尚、福山剛男、坂本邦宏 ; くり返し走行実験に よる自動車運転者の経路選択機構とその変容に関する 研究, 土木計画学研究・論文集 No.16 (掲載決定)

13) Kunihiro SAKAMOTO, Hisashi KUBOTA, Nobuo TAKAHASHI, Takao SUGIURA, Nobuaki IWAZAKI; Micro Simulation for Traffic Assignment Model Applicable to On-Trip Driver Information System : tiss-NET WIN, 2nd World Congress of Intelligent Transportation Systems, pp.1926-1933, 1995

個人の経路変更可能性に着目した動的地区交通シミュレーションモデルの開発

地区交通レベルにおいて交通シミュレーションが盛んに利用されてきている。地区レベルにおいては自動車連転 者の経路選択行動などミクロな交通現象を無視することができない。しかし、これまでに確立されてきた交通シミ ユレーションで自動車運転者の経路選択行動を表現するには多くの課題が残されている。

そこで本研究では、複雑な経路選択メカニズムを疑似行動モデルによって表現するため、実走行実験により経路 選択に影響を及ぼしている要因を提案し、モデル化を行った。このモデルを交通シミュレーションシステム tissNETに組み込むことによって、自動車運転者の動的な経路選択行動がシミュレーション上で表現可能となった。

The Development of Traffic Simulation Model for Personal Route Change Possibility

By Morihisa KIKUCHI, Kunihiro SAKAMOTO and Hisashi KUBOTA

Traffic Simulation is frequently used for micru area network. In micro area network, wc can't ignore the drivers' route choice behavior. But there are many question that is to express the drivers' route choice behavior in traffic simulation.

In this paper, we express simple behavior model to complicated route choice mechanism. And we analyze the factor of route choice and model it. To apply this model to Traffic Simulation System - tiss-NET, we can express the dynamic route choice behavior on traffic simulation system. 